\title{
The Detection Evaluation and Reinforcement Research of Kankan River Bridge
}

\author{
Juxian Liu \\ Institute of Civil Engineering and Construction, Chongqing Jiaotong University, Chongqing, China \\ Email: 2236076356@qq.com
}

Received 24 June 2015; accepted 18 July 2015; published 21 July 2015

Copyright (C) 2015 by author and Scientific Research Publishing Inc. This work is licensed under the Creative Commons Attribution International License (CC BY). http://creativecommons.org/licenses/by/4.0/

(c) (i) Open Access

\begin{abstract}
This design is about Chongqing Wanzhou district KanKan river crossing test evaluation and reinforcement renovation. The bridge is an open spandrel stone arch bridge. After years of operating, defects arise from different parts. To verify whether the bridge meets the bearing capacity of highway grade I standard, this design firstly evaluates the bridge through the apparent diseases. Then it uses Midas/Civil to calculate the bearing capacity of lateral control section for Zhou Jiaba arch foot, $L / 4$ and arch section. Using Midas/Civil control section load calculation, load test plan is made. In the end, by increasing cross-section method, the bridge reinforcement maintenance plan is made; that is increasing abdominal $26 \mathrm{~cm}$ concrete layer in the main arch ring of arch so that the bridge meets grade I highway capacity requirements.
\end{abstract}

\section{Keywords}

Stone Arch Bridge, Inspection and Evaluation, Bearing Capacity, Midas/Civil, Reinforcement and Reconstruction

\section{Introduction}

As one kind of traditional basic bridge type in our country, arch bridge can use local materials thus getting a low cost. With a long history and good appearance, its simple construction does not need large hoisting equipment and high technology. During our bridge history, stonearchbridge plays a decisive role [1]. Taking the Zhaozhou Bridge as an example, it is not only famous for the long history, but also known for the stable structure. What's more, though the bridge suffered from wars in modern history, it is still in a good condition and plays an important part in traffic development. 
In southwest areas, bridges play a necessary role in improving traffic conditions naturally because of the difficult mountainous and streamy terrains. What's more, thanks to the limited ancient architecture technology and beautiful shape with low cost, stone arch bridge construction is preferred. As time goes by, the traffic volume is increasing and original design of the bridge load rating has gone far enough. Different sorts of diseases gradually emerge when bridge service life is too long. However, one certain disease does not mean that the bridge has lost its basic functions. We can completely make use of disease detection assessment and structure bearing capacity calculation to determine whether a disease of the bridge influences its normal work. Or the bearing capacity can improve or not after reinforcement design. It is very important for a bridge to determine whether to leave the stage of transportation history.

\section{Project Profile}

KanKan river bridge is $60 \mathrm{~m}$ long in total and it's an open spandrel stone arch bridge with uniform section of 48 $\mathrm{m}$ clear span and $8 \mathrm{~m}$ arch rise. The straight bridge deck arrangement is: $12 \mathrm{~m}$ (traffic lane) $+2 \times 0.25 \mathrm{~m}$ (handrail) $+2 \times 2.5 \mathrm{~m}$ (side pavement $)=17.5 \mathrm{~m}$.

The bridge was completed in the year of 2001 and design and construction information is limited. After years of operating, the cantilever beams of upstream side of the sidewalk emerged a large number of cracks. To ensure the safety of pedestrians, the maintenance department closed the traffic of sidewalk at upstream side. And in July 2009, the maintenance department continued to construct sidewalk railings on the downstream side.

The bridge is an open spandrel stone arch bridge and arch axis line of the main arch is parabola. The height and width of main arch ring is $1.1 \mathrm{~m}$ and $9.5 \mathrm{~m}$ respectively. The net span of the main arch is $48 \mathrm{~m}$, computing span is $49.1 \mathrm{~m}$, regardless of $49.1 \mathrm{~m}$ calculated span. The foremost photo of the bridge is as Figure 1. Remaining correlation coefficients are as Table 1.

\section{Inspection and Calculation of carrying Capacity of the Bridge}

\subsection{The Finite Element Calculation Model}

1) The upper structure geometry sizes and material performance parameters can be seen as Table 2.

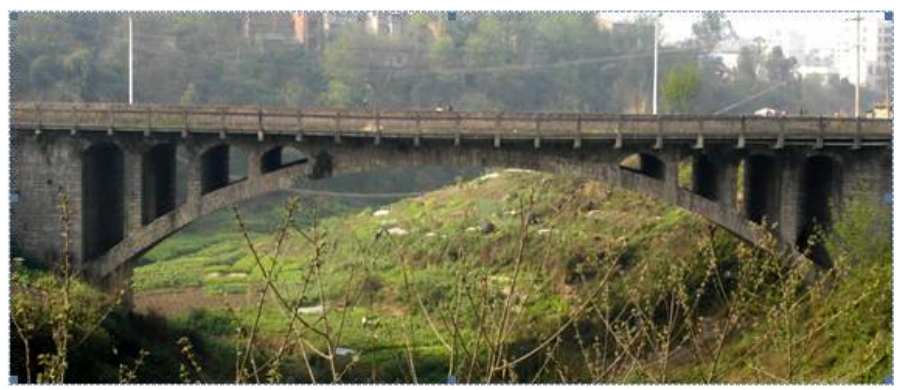

Figure 1. Foremost photo of the bridge.

Table 1. Main design parameters of the arch axis.

\begin{tabular}{cccccc}
\hline Components & Vector span ratio & Net arrow height $(\mathrm{m})$ & Calculated rise of arch $(\mathrm{m})$ & Clear span $(\mathrm{m})$ & Calculated span $(\mathrm{m})$ \\
\hline Main arch & $1 / 6$ & 8 & 8.55 & 48 & 49.1 \\
\hline
\end{tabular}

Table 2. Bridge superstructure geometry and material properties.

\begin{tabular}{ccccccccc}
\hline \multirow{2}{*}{ Component } & \multicolumn{2}{c}{ Sectional dimension } & \multicolumn{4}{c}{ Material parameters } \\
\cline { 2 - 7 } & $\mathrm{h}$ & $\mathrm{b}$ & $f_{c d}$ & $\mathrm{E}$ & $v$ & $\gamma$ & Practical materials \\
\hline Main arch & 1.1 & 9.5 & 3.44 & 7300 & 0.1666 & 24 & M10 mortar + MU40 masonry \\
Abdominal arch & 0.3 & 9.5 & 3.44 & 7300 & 0.1666 & 24 & M10 mortar + MU40 masonry \\
Arch filler & - & 9.5 & 2.73 & 4000 & 0.1666 & 17 & M5.0 mortar + MU50 masonry \\
\hline
\end{tabular}


2) It does not consider the combined effects of the spandrel construction in the arch calculation and in the structural calculation, MIDAS/Civil is adopted to check the strength of cross section under Highway I-level load. In the MIDAS/Civil model, the entire main bridge is analyzed through plane bar system and it is divided into 40 beam elements. And spandrel walls are successively divided into 2,3 and 4 elements. The weight of arch filler and deckpavement replaced with the same amount of vertical unit load. Then the deck system can naturally be replaced by a virtual deck. The width of that virtual deck is $17.5 \mathrm{~m}$ and weight regardless. The bridge is 142 nodes and 144 elements in total. The boundaryconditions adopted in the calculation are: a) arch springing fixed; b) the connection of virtual deck with main arch and abdominal arch is rigid connection in elastic connection series; c) constraints of spandrel walls on the main arch should be released.

Specific division of nodes and elements are as Figure 2.

\subsubsection{Dead Load}

The weight of main arch, abdominal arches and spandrel walls are all calculated by gravity load. In the finite element model, arch filler and deckpavement loads are distributed linearly acting on respective unit of main arch and abdominal arches. The main arch and abdominal arches are divided into element nodes as Figure 3.

According to model calculations, element's dead load intensity of solid-web section on main arch can be get as Table 3.

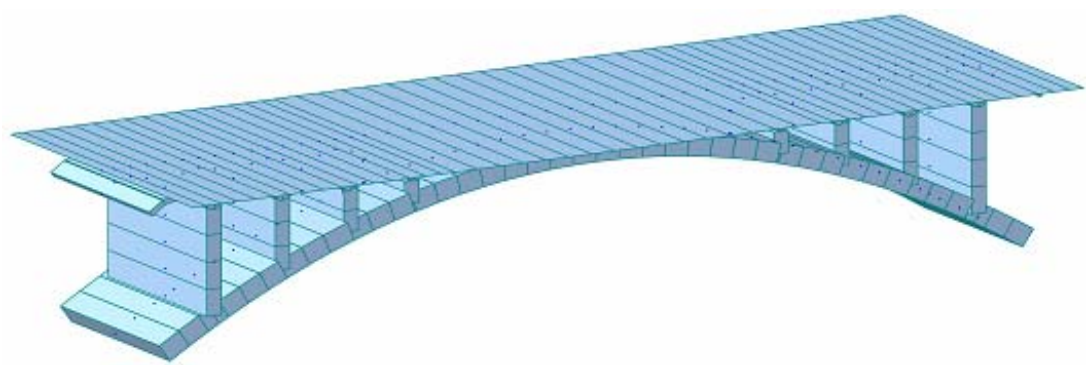

Figure 2. Midas/civil calculationmodel.

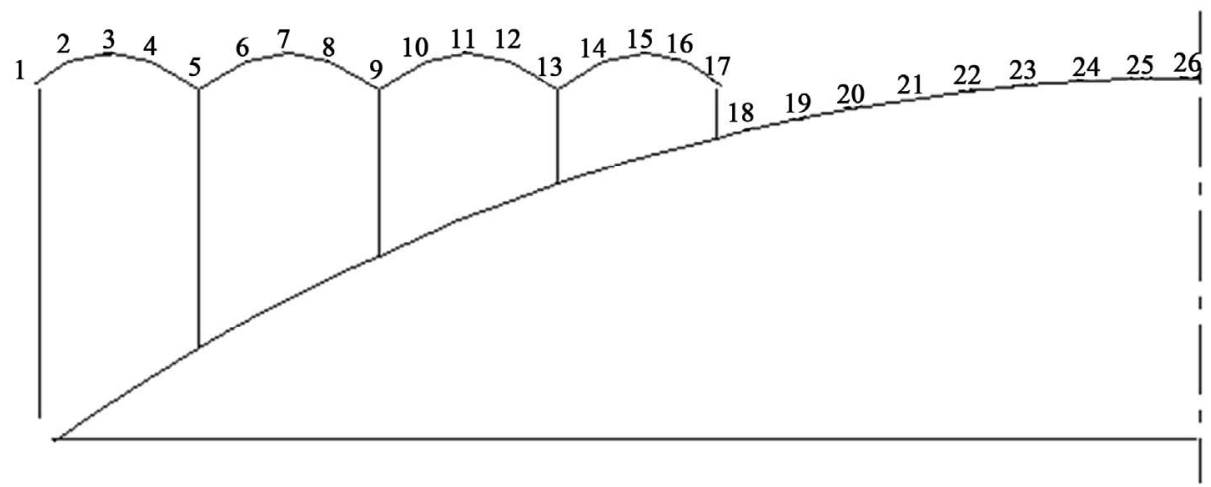

Figure 3. Element nodes main arch and abdominal arches.

Table 3. Element's dead load intensity of solid-web section on main arch $(\mathrm{KN} / \mathrm{m})$.

\begin{tabular}{cccccccccc}
\hline Node number & 1 & 2 & 3 & 4 & 5 & 6 & 7 & 8 & 9 \\
Intensity & 208.9 & 175.5 & 143.6 & 175.5 & 208.9 & 175.5 & 143.6 & 175.5 & 280.9 \\
Node number & 10 & 11 & 12 & 13 & 14 & 15 & 16 & 17 & 18 \\
Intensity & 175.5 & 143.6 & 175.5 & 280.9 & 175.5 & 143.6 & 175.5 & 280.9 & 351.5 \\
Node number & 19 & 20 & 21 & 22 & 23 & 24 & 25 & 26 & \\
Intensity & 305.8 & 265.9 & 231.9 & 203.6 & 181.2 & 164.7 & 154.1 & 149.4 \\
\hline
\end{tabular}




\subsubsection{Live Load and Temperature Load}

Vehicle load is calculated by standard vehicle and according to General Specification for Highway Bridge Design (JTG-D60-2005), the bridge deck is loaded at the most unfavorable position. Four lanes are arranged oneway and two $2.5 \mathrm{~m}$ widthside walks are on the each side. Lane eccentricity is $4.6 \mathrm{~m}, 1.5 \mathrm{~m}$ and $4.7 \mathrm{~m}, 1.6 \mathrm{~m}$ respectively. Sidewalk eccentricity is $7.25 \mathrm{~m}$.

Temperature effect is adopted according to current criterion and $\pm 15^{\circ} \mathrm{C}$ temperature change is set.

\subsection{Arch Internal Force Calculation}

Internal force calculation results of separate dead load, live load and temperature load on the control section of main arch foot, $\mathrm{L} / 4$ main arch and arch crown can be got as Table 4 .

In the model calculations, force state(including temperature change load) of main arch foot, L/4 main arch (L is clear span) and arch crown sections can be composited as following types: basic combination of ultimate limit state, short-term effect combination of serviceability limit state, long-term effect combination of serviceability limit state. The obtained internal force results in main arch sections are shown in the following Tables 5-7.

Table 4. Internal force of the main arch control section under highway I-level load summary.

\begin{tabular}{cccccccc}
\hline \multirow{2}{*}{ Operating Condition } & \multicolumn{2}{c}{ Section } & \multicolumn{2}{c}{ Main arch foot section } & \multicolumn{2}{c}{$\mathrm{L} / 4$ main arch section } & \multicolumn{2}{c}{ Arch crown section } \\
\cline { 3 - 7 } 1 & $\mathrm{~N}(\mathrm{kN})$ & $\mathrm{M}(\mathrm{kN} \cdot \mathrm{m})$ & $\mathrm{N}(\mathrm{kN})$ & $\mathrm{M}(\mathrm{kN} \cdot \mathrm{m})$ & $\mathrm{N}(\mathrm{kN})$ & $\mathrm{M}(\mathrm{kN} \cdot \mathrm{m})$ \\
\hline 2 & Self-weight & -2924.69 & -9858.28 & -23985.92 & 3020.35 & -22971.03 & -3037.38 \\
3 & Temperature load (+) & -121.9 & 771.75 & -279.23 & 5.53 & -346.93 & -524.65 \\
4 & Temperature load (-) & 121.9 & -771.75 & 279.23 & -5.53 & 346.93 & 524.65 \\
5 & Vehicleload (Max) & 0 & 1634.01 & 0 & 1505.5 & 0 & 1741.71 \\
6 & Pedestrian load (Max) & 0 & 435.76 & 0 & 223.36 & 0 & 195.69 \\
7 & Vehicle load (Min) & -1824.16 & -2430.35 & -1689.06 & -885.97 & -1596.05 & -588.58 \\
\hline
\end{tabular}

Table 5. Internal force results at basic combination of ultimate limit state.

\begin{tabular}{|c|c|c|c|c|c|c|c|}
\hline \multirow[b]{2}{*}{ Section } & Combination & \multicolumn{2}{|c|}{ Main arch foot section } & \multicolumn{2}{|c|}{$\mathrm{L} / 4$ main arch section } & \multicolumn{2}{|c|}{ Arch crown section } \\
\hline & & $\mathrm{N}(\mathrm{kN})$ & $\mathrm{M}(\mathrm{kN} \cdot \mathrm{m})$ & $\mathrm{N}(\mathrm{kN})$ & $\mathrm{M}(\mathrm{kN} \cdot \mathrm{m})$ & $\mathrm{N}(\mathrm{kN})$ & $\mathrm{M}(\mathrm{kN} \cdot \mathrm{m})$ \\
\hline & $\operatorname{Max}(\mathrm{T}+)$ & -29365.16 & -6465.73 & -24259.57 & 5312.16 & -23311.02 & -956.59 \\
\hline & $\operatorname{Max}\left(\mathrm{T}^{-}\right)$ & -29126.23 & -7978.37 & -23712.27 & 5301.33 & -22631.03 & 71.72 \\
\hline & $\operatorname{Min}(T+)$ & -32419.86 & -12893.72 & -27067.24 & 1605.41 & -25971.56 & -4515.15 \\
\hline & $\operatorname{Min}\left(T^{-}\right)$ & -32180.94 & -14406.35 & -26519.95 & 1594.58 & -25291.57 & -3486.83 \\
\hline
\end{tabular}

Table 6. Internal force results at long-term effect combination of serviceability limit state.

\begin{tabular}{|c|c|c|c|c|c|c|}
\hline \multirow[b]{2}{*}{ Section } & \multicolumn{2}{|c|}{ Main arch foot section } & \multicolumn{2}{|c|}{$\mathrm{L} / 4$ main arch section } & \multicolumn{2}{|c|}{ Arch crown section } \\
\hline & $\mathrm{N}(\mathrm{kN})$ & $\mathrm{M}(\mathrm{kN} \cdot \mathrm{m})$ & $\mathrm{N}(\mathrm{kN})$ & $\mathrm{M}(\mathrm{kN} \cdot \mathrm{m})$ & $\mathrm{N}(\mathrm{kN})$ & $\mathrm{M}(\mathrm{kN} \cdot \mathrm{m})$ \\
\hline $\operatorname{Max}(\mathrm{T}+)$ & -29343.21 & -8412.97 & -24209.3 & 3716.32 & -23248.57 & -2682.14 \\
\hline $\operatorname{Max}\left(\mathrm{T}^{-}\right)$ & -29148.17 & -9647.77 & -23762.54 & 3707.37 & -22693.48 & -1842.7 \\
\hline $\operatorname{Min}(\mathrm{T}+)$ & -30323.32 & -10407.65 & -25106.42 & 2580.38 & -24100.03 & -3762.33 \\
\hline $\operatorname{Min}\left(T^{-}-\right)$ & -30128.28 & -11642.46 & -24659.65 & 251.54 & -23544.94 & -2922.89 \\
\hline
\end{tabular}


Table 7. Internal force results at short-term effect combination of serviceability limit state.

\begin{tabular}{|c|c|c|c|c|c|c|c|}
\hline \multirow[b]{2}{*}{ Section } & \multirow{2}{*}{$\begin{array}{c}\text { Combination } \\
\text { type }\end{array}$} & \multicolumn{2}{|c|}{ Main arch foot section } & \multicolumn{2}{|c|}{$\mathrm{L} / 4$ main arch section } & \multicolumn{2}{|c|}{ Arch crown section } \\
\hline & & $\mathrm{N}(\mathrm{kN})$ & $\mathrm{M}(\mathrm{kN} \cdot \mathrm{m})$ & $\mathrm{N}(\mathrm{kN})$ & $\mathrm{M}(\mathrm{kN} \cdot \mathrm{m})$ & $\mathrm{N}(\mathrm{kN})$ & $\mathrm{M}(\mathrm{kN} \cdot \mathrm{m})$ \\
\hline & $\operatorname{Max}(\mathrm{T}+)$ & -29343.21 & -7661.3 & -24209.3 & 4301.99 & -23248.57 & -2042.22 \\
\hline & $\operatorname{Max}(\mathrm{T}-)$ & -29149.17 & -8896.11 & -23762.54 & 4293.14 & -22693.48 & -1202.78 \\
\hline & $\operatorname{Min}(\mathrm{T}+)$ & -31246.23 & -11429.71 & -25945.38 & 2179.59 & -24998.39 & -4043.61 \\
\hline & $\operatorname{Min}(\mathrm{T}-)$ & -31051.19 & -12663.51 & -25498.61 & 2170.75 & -24343.3 & -3204.17 \\
\hline
\end{tabular}

\subsection{Load-Carrying Capacity Assessment}

After we analyze the specific internal force, according to Examination and evaluation procedures of the carrying capacity of highway bridge (JTG/T J21-2011) [2], we can get the following evaluation results in main arch sections as Tables 8-10.

After the adoption of Midas/Civil modeling calculation, we can analyze that under the ultimate limit state, in some critical sections, action effects are not satisfied with all the cases of section strength. In the long-term effects limit state combinations, strength of all the main arch foot sections cannot meet criterion requirements and. As for L/4 main arch sections, the maximum effect of the combination is not satisfied with the strength requirements except that the minimumvalue can meet the requirements. When it comes to arch crown sections, in addition to the effect of temperature rise at the minimum state is not satisfied with the strength requirement, the remaining three effects are all can meet the criterion requirements. The same strength calculation results can be seen at the L/4 main arch sections under the short-term effect combination of serviceability limit state [3].

So we should take some measures to the bridge based on the results that some sections cannot meet the strength requirements. Reinforcement scheme is formulated.

\section{Reinforcement Design}

\subsection{Deck Pavement Reconstruction}

The bridgedecksystem shoes some serious diseases, such as serious damage to the upstream side of the sidewalk, partial bridge deck collapse and water logging, serious cracks, expansion joints cracked, bridge deck seepage serious and so on. Therefore, a comprehensive renovation of the bridge deck system is needed including re-pavement, bridge deck waterproofing layer setting and repairing the crash barriers. Some details are as follows [4]:

1) Demolition of the original bridge deck pavement and the rails;

2) Do bridge deck pavement, and then pour crash barrier;

3) Bridge deck pavement: bridge construction from bottom to top is M5 mortar stone masons MU30 sheet filler $+20 \mathrm{~cm}$ thick cement stabilized gravel + waterproof adhesive coating $\mathrm{C} 40+25 \mathrm{~cm}$ thick reinforced concrete pavement;

4) The new bridge deck elevation should be consistent with the original one and it requires that the road surface is along both ends of the elevation. Bridge two-way cross slope is set to $1.5 \%$.

\subsection{The Reinforcement of the Main Arch}

1) $\mathrm{C} 40$ reinforced concrete is adopted. Concrete aggregates choose coarse sand and fine sand shall not be used. The thickness of the main arch reinforcement layer is $26 \mathrm{~cm}$, and longitudinal reinforcement arranged in the upper and lower edges of the new arch, leaving $3 \mathrm{~cm}$ of the concrete cover and each side of the transverse direction shall stay $5 \mathrm{~cm}$ protective layer thickness, transverse reinforcement fabric close to longitudinal reinforcement to decorate, the abutment increasing thickness of $40 \mathrm{~cm}$ [5]. Transverse reinforcement bars are arranged next to the longitudinally ones. The thickening layers at the abutment is $40 \mathrm{~cm}$ thick [6] [7].

2) Steel requirements: HRB335 reinforced steels are selected (characteristic value of strength is $335 \mathrm{MPa}$, tensile strength is $280 \mathrm{MPa}$, compressivestrength is $280 \mathrm{MPa}$ ). And nominal diameters are $18 \mathrm{~mm}$ and $22 \mathrm{~mm}$, where the need for welding steel should meet the requirements of the solderability. Connector rate of reinforced connecting segments can be no more than $50 \%$. 
Table 8. Strength calculation results at basic combination of ultimate limit state.

\begin{tabular}{|c|c|c|c|c|c|c|}
\hline Section & Load combination type & $\mathrm{N}(\mathrm{kN})$ & $\mathrm{M}(\mathrm{kN} \cdot \mathrm{m})$ & $\varphi$ & $\mathrm{R}(\mathrm{kN})$ & Meet the specification or not \\
\hline \multirow{4}{*}{$\begin{array}{l}\text { Main arch } \\
\text { foot section }\end{array}$} & $\operatorname{Max}(\mathrm{T}+)$ & -29365.16 & -6465.73 & 0.62 & -19183 & No \\
\hline & $\operatorname{Max}\left(\mathrm{T}^{-}\right)$ & -29126.23 & -7978.37 & 0.52 & -55925 & Yes \\
\hline & $\operatorname{Min}(T+)$ & -32419.86 & -12893.72 & 0.31 & -9601 & No \\
\hline & $\operatorname{Min}\left(T^{-}\right)$ & -32180.94 & -14406.35 & 0.23 & -130147 & Yes \\
\hline \multirow{4}{*}{$\begin{array}{l}\mathrm{L} / 4 \text { main arch } \\
\text { section }\end{array}$} & $\operatorname{Max}(\mathrm{T}+)$ & -24259.57 & 5312.16 & 0.63 & -19258 & No \\
\hline & $\operatorname{Max}(\mathrm{T}-)$ & -23712.27 & 5301.33 & 0.62 & -18973 & No \\
\hline & $\operatorname{Min}(\mathrm{T}+)$ & -27067.24 & 1605.41 & 0.92 & -28234 & Yes \\
\hline & $\operatorname{Min}\left(T^{-}\right)$ & -26519.95 & 1594.58 & 0.92 & -28206 & Yes \\
\hline \multirow{4}{*}{$\begin{array}{l}\text { Arch crown } \\
\text { section }\end{array}$} & $\operatorname{Max}(\mathrm{T}+)$ & -23311.02 & -956.59 & 0.94 & -28772 & Yes \\
\hline & $\operatorname{Max}\left(\mathrm{T}^{-}\right)$ & -22631.03 & 71.72 & 0.95 & -29280 & Yes \\
\hline & $\operatorname{Min}(T+)$ & -25971.56 & -4515.15 & 0.72 & -22111 & No \\
\hline & $\operatorname{Min}(T-)$ & -25291.57 & -3486.83 & 0.79 & -24350 & No \\
\hline
\end{tabular}

Table 9. Strength calculation results at long-term effect combination of serviceability limit state.

\begin{tabular}{|c|c|c|c|c|c|c|}
\hline Section & Load combination type & $\mathrm{N}(\mathrm{kN})$ & $\mathrm{M}(\mathrm{kN} \cdot \mathrm{m})$ & $\varphi$ & $\mathrm{R}(\mathrm{kN})$ & Meet the specification or not \\
\hline \multirow{4}{*}{$\begin{array}{l}\text { Main arch } \\
\text { foot section }\end{array}$} & $\operatorname{Max}(\mathrm{T}+)$ & -29343.21 & -8412.97 & 0.50 & -15262 & No \\
\hline & $\operatorname{Max}\left(\mathrm{T}^{-}\right)$ & -29148.17 & -9647.77 & 0.42 & -12912 & No \\
\hline & $\operatorname{Min}(\mathrm{T}+)$ & -30323.32 & -10407.65 & 0.40 & -12292 & No \\
\hline & $\operatorname{Min}\left(\mathrm{T}^{-}\right)$ & -30128.28 & -11642.46 & 0.33 & 10157 & No \\
\hline \multirow{4}{*}{$\begin{array}{l}\mathrm{L} / 4 \text { main } \\
\text { arch section }\end{array}$} & $\operatorname{Max}(\mathrm{T}+)$ & -24209.3 & 3716.32 & 0.76 & -23392 & No \\
\hline & $\operatorname{Max}\left(\mathrm{T}^{-}\right)$ & -23762.54 & 3707.47 & 0.76 & -23235 & No \\
\hline & $\operatorname{Min}(\mathrm{T}+)$ & -25106.42 & 2580.38 & 0.86 & -26333 & Yes \\
\hline & $\operatorname{Min}\left(\mathrm{T}^{-}\right)$ & -24659.65 & 2571.54 & 0.85 & -26255 & Yes \\
\hline \multirow{4}{*}{$\begin{array}{l}\text { Arch crown } \\
\text { section }\end{array}$} & $\operatorname{Max}(\mathrm{T}+)$ & -23248.57 & -2682.14 & 0.83 & -25656 & Yes \\
\hline & $\operatorname{Max}\left(\mathrm{T}^{-}\right)$ & -22693.48 & -1842.7 & 0.89 & -27373 & Yes \\
\hline & $\operatorname{Min}(T+)$ & -24100.03 & -3762.33 & 0.76 & -23229 & No \\
\hline & $\operatorname{Min}(\mathrm{T}-)$ & -23544.94 & -2922.89 & 0.82 & -25159 & Yes \\
\hline
\end{tabular}

Table 10. Strength calculation results short-term effect combination of serviceability limit state.

\begin{tabular}{|c|c|c|c|c|c|c|}
\hline Section & Load combination type & $\mathrm{N}(\mathrm{kN})$ & $\mathrm{M}(\mathrm{kN} \cdot \mathrm{m})$ & $\varphi$ & $\mathrm{R}(\mathrm{kN})$ & Meet the specification or not \\
\hline \multirow{4}{*}{$\begin{array}{l}\text { Main arch } \\
\text { foot section }\end{array}$} & $\operatorname{Max}(\mathrm{T}+)$ & -29343.21 & -7661.3 & 0.54 & -16716 & No \\
\hline & $\operatorname{Max}\left(\mathrm{T}^{-}\right)$ & -29148.17 & -8896.11 & 0.46 & -14257 & No \\
\hline & $\operatorname{Min}(T+)$ & -31246.23 & -11428.71 & 0.36 & -11172 & No \\
\hline & $\operatorname{Min}\left(T^{-}\right)$ & -31051.19 & -12663.51 & 0.30 & -9099 & No \\
\hline \multirow{4}{*}{$\begin{array}{c}\mathrm{L} / 4 \text { main } \\
\text { arch section }\end{array}$} & $\operatorname{Max}(\mathrm{T}+)$ & -24209.3 & 4301.99 & 0.71 & -21867 & No \\
\hline & $\operatorname{Max}\left(\mathrm{T}^{-}\right)$ & -23762.54 & 4293.14 & 0.71 & -21678 & No \\
\hline & $\operatorname{Min}(\mathrm{T}+)$ & -25945.38 & 2179.59 & 0.89 & -27248 & Yes \\
\hline & $\operatorname{Min}\left(T^{-}\right)$ & -25498.61 & 2170.75 & 0.88 & -27197 & Yes \\
\hline \multirow{4}{*}{$\begin{array}{l}\text { Arch crown } \\
\text { section }\end{array}$} & $\operatorname{Max}(\mathrm{T}+)$ & -23248.57 & -2042.22 & 0.88 & -27071 & Yes \\
\hline & $\operatorname{Max}\left(\mathrm{T}^{-}\right)$ & -22693.48 & -1202.78 & 0.93 & -28440 & Yes \\
\hline & $\operatorname{Min}(\mathrm{T}+)$ & -24898.39 & -4043.61 & 0.74 & -22835 & No \\
\hline & $\operatorname{Min}\left(T^{-}\right)$ & -24343.3 & -3883.16 & 0.80 & -24722 & Yes \\
\hline
\end{tabular}




\section{Evaluation of the Reinforcement Scheme}

The commonly used reinforcement methods are FRP, steel plate and the traditional section increment method etc. CFRP SHEETS method is mainly used to prevent the development of cracks, and for horizontal and vertical cracks appearing on piers, CFRP can effectively suppress the development of cracks. Pasting steel sheets can effectively improve the overall strength of the bridge [8]. When the bridge bearing capacity is insufficient, it is used to improve the bearing capacity of main girder and adopted at the bottom of the main girder. It is also used for arch bridge reinforcement. The method of enlarged cross section is common in the arch bridge reinforcement project and is commonly used in the main arch ring when bearing capacity is insufficient. Our bridge is strengthened by increasing the cross section. The reason to choose the methods is the long history of the bridge. Increasing section method can obviously improve the carrying capacity of the bridge and enlarged cross section is equipped with steels which can increase the lifespan of the masonry arch bridge to a certain extent. From the long-term interests, it is superior compared with bonding carbon fiber sheets and pasting steel plates.

\section{References}

[1] Zhou, S.X. (2011) Bridge Engineering. Chongqing University Press, Chongqing.

[2] Highway Bridge Technical Condition Assessment Standards (JTGT H21-2011) (2011) China Communications Press, Beijing.

[3] Washer, G.A. (1998) Developments for the Non-Destruction Evaluation of Highway Bridges in the USA. NDT \& E International, 31, 245-249. http://dx.doi.org/10.1016/S0963-8695(98)00009-7

[4] Highway Bridges Reinforcement Design Specification (JTGT J22-2008) (2008) China Communications Press, Beijing.

[5] Meng, Y. and Lu, B. (2004) Bridge Reinforcement and Reconstruction. China Communications Press, Beijing.

[6] General Specification for Highway Bridge Design (JTG D60-2004) (2004) China Communications Press, Beijing.

[7] Highway Masonry Bridge Design Specifications (JTG D61-2005) (2005) China Communications Press, Beijing.

[8] Housner, G.W., Bergman, L.A., Caughey, T.K., et al. (1997) Structural Control: Past, Present, and Future. Journal of Engineering Mechanics, 123, 897-971. http://dx.doi.org/10.1061/(ASCE)0733-9399(1997)123:9(897) 